\title{
Extraction of Mucilage from Chia Seeds and its Application as Fat Replacer in Biscuits
}

\author{
Sameera Nayani, Subba Rao D \\ Jawaharlal Nehru Technological University \\ Ananthapur, Andhra Pradesh, India - 515002
}

\begin{abstract}
Chia seeds (Salvia hispanica L.) are considered as one of the "Superfoods" due to its high nutritional value. They are good source of dietary fiber, protein and unsaturated fats. Application of mucilage from chia seeds in food industry has been of interest lately. There are no commercially viable techniques to extract and separate mucilage due to its limited research, low extractability and yield. In the present study, chia mucilage is extracted from white chia seeds by a novel thermal process. The extracted mucilage powder is reconstituted and further incorporated into the biscuits as a gel and investigated for the effect of partial fat substitution $(20 \%$ to $40 \%)$ on physical properties (spread ratio, color, and texture profile), chemical properties (carbohydrates, protein, fat and ash) and sensory evaluation of biscuits along with the control sample. The yield of mucilage obtained through novel method is $8 \%$. Addition of chia mucilage gel had a positive effect on hardness of biscuits. The color of the biscuits changed from light brown to creamy yellow as the level of mucilage gel increased. The sensory properties of the biscuit were strongly influenced by the mucilage gel level. By considering the overall acceptability of the biscuits, the use of chia mucilage gel can be considered as a potential fat replacer.
\end{abstract}

Keywords-Chia seeds. chia mucilage gel, fat replacer, viscosity of mucilage gel.

\section{INTRODUCTION}

Chia (Salvia hiapanica) is an edible seed which is native from southern Mexico. Chia seeds are good source of dietary fiber, protein, antioxidants and poly unsaturated fats such as linoleic and lenolenic acids [1]. Chia seeds are considered as "Super food" and commercially available in India. Due to its nutritional properties and fat binding properties, inclusion of chia flour is considered as value addition in bakery products [2]. When chia seed is immersed in water, a transparent capsule is exuded around the seed known as "mucilage [3]. The high water holding capacity and soluble fiber nature of chia seeds is due to its complex structure which is proposed to be tetrasaccharide with 4-O-methyl-aDglucoronopyranosyl units occurring as branches of b-Dxylopyranosyl on the main chain. [4]. The extraction of mucilage from chia seeds is prolonged process and can't be separated easily. Various studies on the extraction of chia seed mucilage has shown yield ranging from 4 to $7 \%$ at temperature $80^{\circ} \mathrm{C}$ [5]. The typical chia mucilage extraction involves hydration, exudation, drying and sieving process. Microwave assisted extraction (MAE) is recent technique which is gaining interest and has potential to extract efficiently when compared to conventional extraction technique. The principle of MAE depends on the ionic conduction and dipole rotation caused by microwaves followed by heat generation which in turn causes the pressure on the cell wall. This pressure allows the constituents to get ruptured from the cell into the solvent present and thus increasing their yield [6]. Using microwave, mucilage has been successfully extracted with more yield in less time from Opuntia ficus indica cladodes when compared to conventional extraction (CE) [7][8].

Health disorders such as obesity, diabetes and heart disease are caused due to excess intake of saturated fats [9]. Currently, consumers' attention is drawn towards low-caloric products, owing to the increasing emphasis on health education. Current major concern in packaged food market is fat reduction and therefore increasing demand for low fat products. According to the reports, in the year 2016, around $13 \%$ of the world's adult population (11\% of men and $15 \%$ of women) were obese [10]. According to recent research reports [11], south Asians are at higher risk for the development of obesity and other non-communicable diseases. Obesity may be related to other noncommunicable diseases [12]. Fat replacement by other substances is a major concern, specifically in bakery products. In biscuits, the addition of fat gives right texture, flavor, mouthfeel and thus contributing to its overall acceptability [13]. Over the years, different carbohydrate-based substances such as maltodextrin [14], polydextrose [15] and inulin [16] that provide similar physical and sensory properties to fats have been used in foods. When used in biscuits, the textural and sensory properties have significantly changed [17][18][19]. Therefore, there is a search for best fat substitute that causes least changes in physico-chemical and sensory properties of food. India is currently the world's largest biscuit consuming nation and is consumed all over the world. Biscuit can contain fat ranging from 16 to $25 \mathrm{gm}$ per $100 \mathrm{~g}$ of the product. Indian biscuit market projected to reach $\$ 7.25$ billion in next four years [20]. Recently, chia mucilage has been studied as a potential fat replacer. Role of chia seed mucilage as a fat replacer has been studied in pound cakes and bread More than $25 \%$ of fat was replaced in pound cakes [21] and $56.6 \%$ in breads [22] without effecting their technological properties. However, its function was not studied in biscuits. Role of chia mucilage as stabilizer and emulsifier also has been studied in ice cream [23].

The objective of this study was to extract chia mucilage through MAE and evaluate the effects of its incorporation on the textural, physiochemical and sensory quality of wheat biscuits with the substitution of 20,30 and $40 \mathrm{~g} / 100 \mathrm{~g}$ of fat. 


\section{MATERIAL AND METHODS}

\section{A. Material}

White chia seeds were donated by M/s. SAMATH, Hyderabad, Telangana. The seeds were commercially grown in the Ananthapur region of Andhra Pradesh. The composition as provided by the supplier: Moisture $<12 \%$, Carbohydrates $40 \%$, Dietary fiber $34 \%$, Protein $17 \%$, and Fat $32 \%$.

\section{B. Chia seeeds hydration}

Chia seed hydration capacities were determined under room temperature conditions $\left(26^{\circ} \mathrm{C}\right)$. Seed to water ratio is maintained at 1: 40 . In a $100 \mathrm{ml}$ beaker, $40 \mathrm{ml}$ of distilled water is taken into which sample of $1 \mathrm{gm}$ of chia seeds were placed separately inside a filter paper bag was immersed .The net weight of each bag was weighed every 10 min until it reached a constant value. The experiment was done in triplicate.

\section{Mucilage extraction by using microwave}

Microwave assisted extraction of mucilage from chia seeds were performed in customized pilot scale microwave oven system with cubical $(2.45 \mathrm{GHz}$, Enerzi Microwave systems pvt ltd, Belgaum, Karnataka). The oven was equipped with digital control system for microwave power which is adjustable from 100 to $2000 \mathrm{~W}$ and also modified to record the temperature of the sample placed by fiber optic temperature probes $\left(-50^{\circ} \mathrm{C}\right.$ to $250^{\circ} \mathrm{C}$ Reflex Make, Canada). Samples of $10 \mathrm{~g}$ of chia seeds were added into $400 \mathrm{ml}$ of distilled water taken in a $500 \mathrm{ml}$ beaker. $\mathrm{pH}$ was adjusted and maintained at 8 . Then the beaker with aqueous suspension was placed into the oven and ran at $1.3 \mathrm{~W} / \mathrm{gm}$ until it reached 80 C. At room temperature, the aqueous suspension was stirred continuously with magnetic stirrer for $30 \mathrm{~min}$. The suspension was filtered for removing any extra water and spread on a tray followed by drying in a hot air oven with forced air circulation at $50^{\circ} \mathrm{C}$ for 12 to 14 hours. The dried seeds were rubbed through a $40 \mathrm{~mm}$ mesh screen to obtain mucilage. The weight was recorded, and yield was calculated. Mucilage gel was prepared by mixing $0.1 \mathrm{gm}$ of dried mucilage in $100 \mathrm{ml}$ of distilled water. This mucilage is further used as fat replacer in wheat biscuits.

\section{Yield of the mucilage and viscosity of the gel}

The yield of the chia mucilage extracted is calculated using following Eq. (1)

$$
Y(\%)=\frac{\text { Wt of mucilage }}{\text { Wt of chia seeds }} \times 100
$$

The viscosity of the hydrated samples $(0.125 \mathrm{~g} / 100 \mathrm{~g})$ was measured using a Hoppler viscosimeter at $25^{\circ} \mathrm{C}$. All analyses were performed in triplicate.

\section{E. Preparation of biscuit}

The composition of ingredients in biscuit formulation is mentioned below (TABLE I). The dough preparation was done in a laboratory mixer. Sugar and fat/ mucilage gel were mixed thoroughly and creamed at low level speed. The ammonium bicarbonate, milk powder, sodium chloride and vanilla essence were added into the flour. After pouring appropriate amount of water, cream was added along and dough was prepared by proper mixing. The biscuits were cut with a round cutter of $40 \mathrm{~mm}$ diameter and baked on an aluminum tray at $180^{\circ} \mathrm{C}$ for $10-12 \mathrm{~min}$. The biscuits were cooled and stored in aluminum pouches for analysis.

TABLE I. BISCUIT COMPOSITION

\begin{tabular}{|c|c|c|c|c|}
\hline \multicolumn{5}{|c|}{ Ingredients of biscuits with varying fat levels } \\
\hline Ingredients & Control & $20 \% F R$ & $30 \% \mathrm{FR}$ & $40 \% \mathrm{FR}$ \\
\hline Wheat & 53.5 & 53.5 & 53.5 & 53.5 \\
\hline Sugar & 14.9 & 14.9 & 14.9 & 14.9 \\
\hline Oil & 16.6 & 13.2 & 11.6 & 9.9 \\
\hline CMG $(0.1 \%)$ & 0.0 & 3.3 & 5.0 & 6.6 \\
\hline Baking Powder & 0.5 & 0.5 & 0.5 & 0.5 \\
\hline Ammonium Carbonate & 0.5 & 0.5 & 0.5 & 0.5 \\
\hline Salt & 0.6 & 0.6 & 0.6 & 0.6 \\
\hline Milk :Powder & 0.8 & 0.8 & 0.8 & 0.8 \\
\hline Essence & 0.4 & 0.4 & 0.4 & 0.4 \\
\hline Water & 12.1 & 12.1 & 12.1 & 12.1 \\
\hline Total & 100 & 100 & 100 & 100 \\
\hline
\end{tabular}

\section{F. Evaluation of biscuit}

1) Physico-chemical properties: The physical properties measured were diameter, thickness, average weight, moisture content, and color. Diameter was measured by placing six biscuits edge to edge and thickness by stacking one biscuit above the other. The average of the three such arrangements were taken and considered. The average weight of six biscuits was noted. Moisture was measured using the methods described by [24]. Spread ratio is calculated by the ratio of diameter and thickness. The colour $(\mathrm{L} * \mathrm{a} *, \mathrm{~b} *)$ values of the sample were measured with a Hunter Lab Colorflex colorimeter (Hunter Associates Laboratory, Reston, Va., U.S.A.) and by taking color group as a reference, total color differences $(\Delta \mathrm{E})$ were calculated.

The total colour difference $(\Delta \mathrm{E})$, in CIE $\mathrm{L} * \mathrm{a} * \mathrm{~b} *$ color model was calculated by the Eq (2) [25]

$$
\Delta E=\sqrt{\left[\left(L *_{2}-L *_{1}\right)+\left(a *_{2}-a *_{1}\right)+\left(b *_{2}-b *_{1}\right)\right]}
$$

where, and indicate colour parameters of raw cookies (dough), parameter $L^{*}$ refers to the lightness of the samples, and ranges from black $(L=0)$ to white $(L=100)$, a negative value of parameter $a^{*}$ indicates green and a positive one indicates red-purple colour, and positive value of parameter $b^{*}$ indicates yellow while negative value indicates blue colour. All measurements were repeated in three replicates. Textural analysis was performed by Texture Pro CT V1.3 (Brookfield Engineering Labs, Inc). Four cookies were evaluated from each sample using the three-point break technique. Test type is compression strength and was used under following conditions: Target mode: distance, distance: $2.5 \mathrm{~mm}$, Pre test speed: $2 \mathrm{~mm} / \mathrm{s}$, test speed: $1 \mathrm{~mm} / \mathrm{s}$, trigger force: $50 \mathrm{~g}$. The hardness $(\mathrm{g})$ and fracturability $(\mathrm{mm})$ were recorded.

The proximate compositions of biscuits were estimated according to [26], on dry basis. The Moisture, total ash, protein, total fat, total carbohydrate content and lipid content were determined. The energy (kcal) of the biscuit was calculated based on the caloric coefficients corresponding to 
the protein, carbohydrate and lipid content, according to Eq. (3)

$$
\begin{aligned}
& \text { Energy }(k \text { cal per } 100 \mathrm{~g}) \\
& =[\text { Quantity of protein in }(g) * 4]+[\text { Quantity of carbohydrate }(g)] * 4
\end{aligned}
$$$$
+[\text { Quantity of lipids }(g) * 9]
$$

2) Sensory properties: The physical properties measured were diameter, thickness, average weight, moisture content, and color. Diameter was measured by placing six biscuits edge to edge and thickness by stacking one biscuit above the other. The average of the three such arrangements were taken and considered. The average weight of six biscuits was noted. Moisture was measured using the methods described by [25]. Spread ratio is calculated by the ratio of diameter and thickness. The colour $(L *, a *, b *)$ values of the sample were measured with a Hunter Lab Colorflex colorimeter (Hunter Associates Laboratory, Reston, Va., U.S.A.) and by taking color group as a reference, total color differences $(\Delta \mathrm{E})$ were calculated.

3) Statistical analysis: All the experiments were done at least in triplicate. The data were compared using analysis of variance (single point ANOVA) and the average values obtained were compared using MS office 2016, with statistical significance (a) set at $\mathrm{p}<0.05$.

\section{RESULTS AND DISCUSSION}

\section{A. Hydration of chia}

Hydration of white chia seeds was studied at a ratio of water to seed ratio of 40: 1 . After $30 \mathrm{~min}$, the total weight of the seeds became constant. Unlike the black chia seeds which takes $2 \mathrm{hrs}$, the hydration time for white chia is less. Fig 1 shows the final water absorption is $83 \%$ indicating that it would require less water for hydration. The test was done at room temperature $\left(28^{\circ} \mathrm{C}\right)$. Water absorption is faster within first 10 min. similar behavior has been reported in the above study on black chia [5].

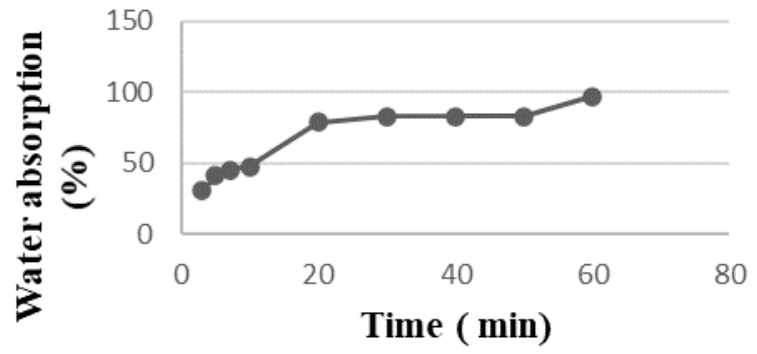

Fig.1. Hydration of Chia seeds

\section{B. Mucilage Extraction}

Mucilage was extracted by using microwave at $1.3 \mathrm{~W} / \mathrm{gm}$ for $15 \mathrm{~min}$. Preliminary studies of time temperature profiles with water in microwave indicated that by application of 1.3 $\mathrm{W} / \mathrm{gm}$, water temperature rises to $80^{\circ} \mathrm{C}$. Time and temperature profile correlated with chia seeds and water suspension. As the hydration studies indicated that it would take $30 \mathrm{~min}$ to reach maximum water absorption, the seed and water suspension were magnetically stirred for another 15 min after microwave treatment.

\section{Yield of the mucilage}

The average yield of mucilage obtained was $8 \%$ through the microwave extraction. The obtained yield is higher than those reported by [23], [27] and [3] but lesser than reported by [28] through conventional extraction methods at $80^{\circ} \mathrm{C}$ with $\mathrm{pH}$ of 8 and seed : water ratio of 1:40. Optimization studies are yet to be done with varying power levels, time and water seed ratio. Extraction time was 4 times lesser than the above reported studies. There were no comparative studies for microwave extraction of mucilage from chia seeds. However, a yield of $8.13 \%, 2 \%$ and $4.6 \%$ was reported for microwave extracted mucilage from Opuntia ficus-indica Cladodes [8], Trichosanthes Dioica fruit [29] and Trigonella foenum graecum seeds [30] respectively.

\section{Viscocity}

It can be observed in the rheogram (Fig.2) that the viscosity decreases with increase shear rate or speed. This behavior is called as shear thinning or pseudoplastic. The reason may be due to the change in the structure or orientation of the mucilage. At higher shear rate, the interaction between the polymers are destroyed as they arrange themselves in the flow direction and in turn resulting in low viscosity [31], [32], [33]. The rheological behaviour of the mucilage extracted through microwave correlates with the mucilage extracted through cold extraction [34], and hot extraction methods [24], [35], [36] and Supercritical Fluid extraction methods [37].

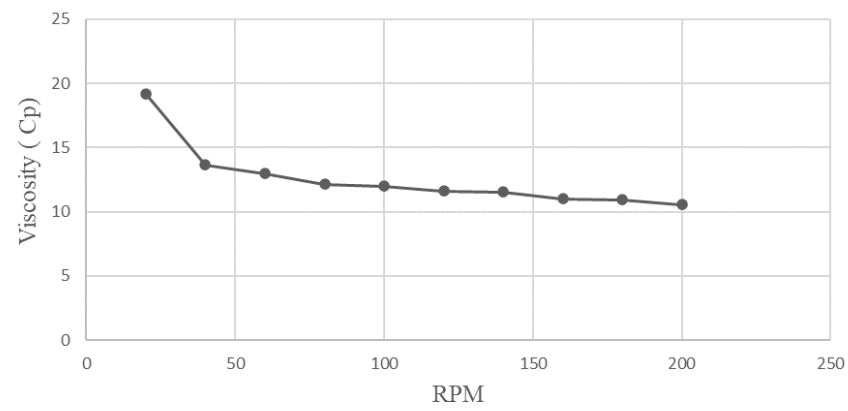

Fig.2. Effect of Shear rate/speed on the viscosity of chia mucilage

\section{E. Physico-chemical properties of biscuit}

Table II presents the physical properties of control biscuit and biscuit with fat replaced by mucilage extracted from chia at three different levels. Moisture content in biscuit is one of the important sensory characteristics and in turn responsible for quality [38]. Moisture content increased with the increase of fat substitution. This is due to the water holding property of the chia mucilage. Similar results were reported by [39] when fat was replaced by chia mucilage gel in bread and cakes. Reduction in weight (mass) of biscuit has been considered as baking loss which is caused by the loss of moisture. Although the initial moisture content of the fat replaced biscuits are high when compared to the control, a significant decrease in weight has been observed in fat replaced samples (TABLE II). Similar observation was reported by [40] while studying the effect of different flour composition on qualitative parameters of cookies.

Texture Analysis In biscuit quality, significant differences were observed in spread ratio, breaking strength and fracturability. The desirability of the biscuit quality is indicated by the higher spread ratio [41]. It is used to determine the quality of flour that enables the biscuit to rise [42]. Hence, biscuit prepared with $35 \%$ fat replacement may 
be the most preferred based on spread ratio. Similar findings with respect to the weight, diameter, and spread ratio were reported by another researcher [43]. For a biscuit, textural parameters are very desirable and important quality attribute. Breaking strength, which is the force $(\mathrm{g})$ required to break the biscuit, increased with the increased percentage of mucilage formulation in biscuit. Biscuits which show high values of breaking strength represent less tenderness. The ability of biscuit to regain its original form is measured in terms of fracturability. Fracturability of the biscuit samples significantly reduced as the level of mucilage increased. Relation between breaking strength and distance $(\mathrm{mm})$ at different fat replacements in biscuits is presented in figure. Biscuits which shows high breaking strength values are less tender. Biscuits which shows greater values of fracturability at breaking strength were less brittle. Control biscuits showed the lowest breaking strength and the lower fracturibility. 20 $\%$ and $30 \%$ fat replaced biscuits showed higher breaking strength and higher fracturibility than control samples. $40 \%$ fat replaced biscuits showed high breaking strength but lower fracturability than control samples (Figure 3). Therefore $30 \%$ fat replaced biscuits were considered as highly compressible and less brittle. [44] reported that at formulations with $30 \%$ fat replacement by polydextrose showed high breaking strength than control cookies. It is reported that $25 \%$ fat replacement in cookies did not affect penetration force [45].

TABLE II. PHYSICAL PROPERTIES

\begin{tabular}{|l|c|c|c|c|c|}
\hline \multicolumn{6}{|c|}{ Physical properties of control and fat replaced (FR) biscuits } \\
\hline Sample & Moisture & $\begin{array}{c}\text { Spread } \\
\text { Ratio }\end{array}$ & $\begin{array}{c}\text { Baking } \\
\text { loss } \\
(\text { g/100gm })\end{array}$ & $\begin{array}{c}\text { Breaking } \\
\text { Strength } \\
(\text { kg) }\end{array}$ & $\begin{array}{c}\text { Fracturatibility } \\
(\text { mm })\end{array}$ \\
\hline Control & $3.77 \pm 0.85^{\mathrm{a}}$ & $5.9 \pm 1.62^{\mathrm{b}}$ & $10.26 \pm 1.33^{\mathrm{b}}$ & $1.8 \pm 1.05^{\mathrm{b}}$ & $0.49 \pm 0.05^{\mathrm{a}}$ \\
\hline $\begin{array}{l}20 \% \\
\text { FR }\end{array}$ & $4.48 \pm 1.70^{\mathrm{b}}$ & $6.1 \pm 0.34^{\mathrm{a}}$ & $13.36 \pm 1.76^{\mathrm{a}}$ & $2.2 \pm 0.18^{\mathrm{a}}$ & $0.59 \pm 0.02^{\mathrm{a}}$ \\
\hline $\begin{array}{l}30 \% \\
\text { FR }\end{array}$ & $6.67 \pm 1.65^{\mathrm{a}}$ & $4.5 \pm 0.22^{\mathrm{b}}$ & $17.39 \pm 0.25^{\mathrm{b}}$ & $2.6 \pm 0.21^{\mathrm{a}}$ & $1.09 \pm 0.06^{\mathrm{b}}$ \\
\hline $\begin{array}{l}40 \% \\
\text { FR }\end{array}$ & $8.46 \pm 0.55^{\mathrm{a}}$ & $4.4 \pm 0.15^{\mathrm{b}}$ & $20.91 \pm 0.88^{\mathrm{b}}$ & $3.4 \pm 0.48^{\mathrm{b}}$ & $0.49 \pm 0.02^{\mathrm{a}}$ \\
\hline
\end{tabular}

Average of three values with standard deviation, same letter in the line indicates that there is no significant difference between the means $(p<0.05)$

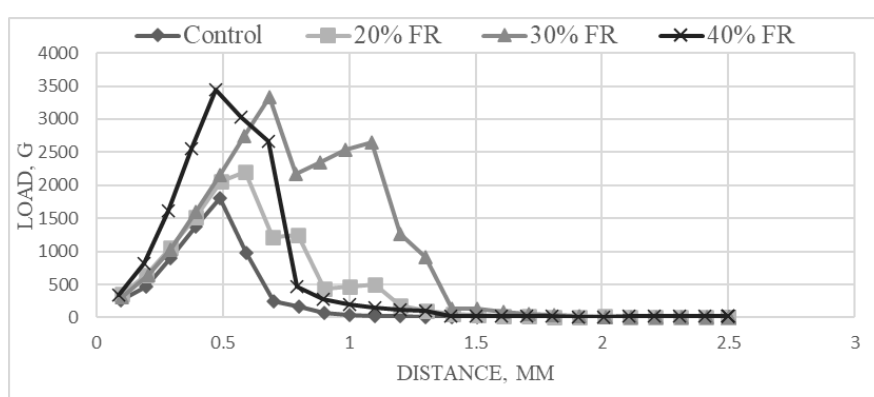

Fig.3. Breaking Strength and fracturibility at different levels of fat replacement(FR)

\section{F. Proximate composition}

Table III presents the proximal composition of control biscuits and in fat replaced biscuits. The increase in percentage of fat substitution resulted in a slightly higher protein content. The energy or caloric value for fat replaced samples was lower because of its highly reduced content of lipids. Significant reduction was reported in fat content of
$56.6 \%$ in breads and $51.6 \%$ in cakes by adding chia mucilage gel and good sensory acceptability [39]. However, results reported by [46] showed a fat reduction of $57 \%$ in cakes but does not have good sensory acceptability. There were no significant changes in ash content of fat replaced formulations.

TABLE III. PROXIMATE COMPOSITION

\begin{tabular}{|c|c|c|c|c|c|}
\hline \multicolumn{6}{|c|}{ Mean values of proximate composition of control and fat replaced biscuits } \\
(in 100g)
\end{tabular}

\section{G. Color measurement}

To observe the undesired color changes, the color of the fat replaces biscuits is measured by comparing with the control sample. The values of color change $(\Delta E)$ and lightness $\left(\mathrm{L}^{*}\right)$ are presented in Fig 4 . There are no significant differences in $a^{*}$ and $b *$ values. [44] reported that there was a significant decrease in $\mathrm{L}^{*}$ values after adding fat mimetics such as polydextrose and pectin. Similarly, [39] reported decrease of $\mathrm{L}^{*}$ values in crust and crumb of breads after adding chia mucilage. In contrary to the above studies $\mathrm{L}^{*}$ values were significantly increased with addition of chia mucilage in the present report.

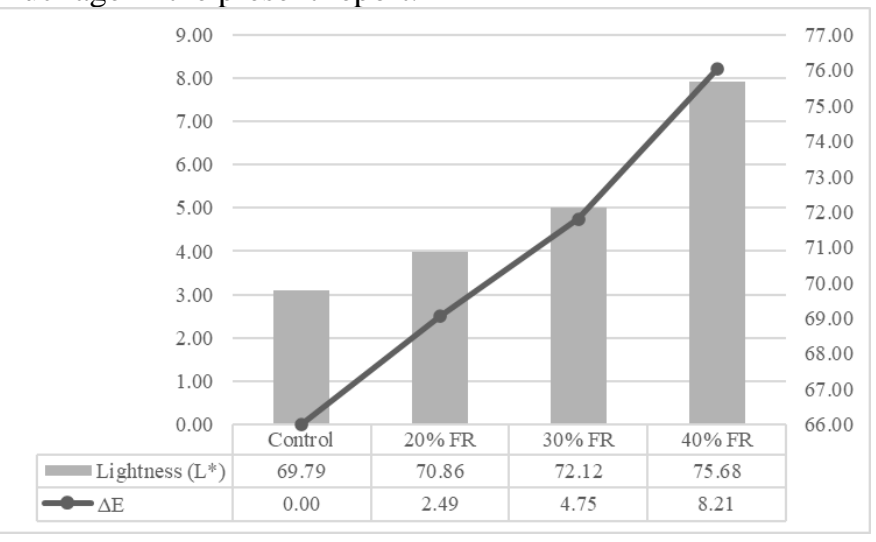

Fig.4. Mean values of color changes in fat replaced (FR) biscuits

\section{H. Sensory Analysis}

Figure 5 presents the sensory analysis results of fat replaced biscuits by comparing with control sample. It can be observed that there was no significant difference upto $20 \%$ fat replacement in biscuits in all the evaluated sensory parameters. Control and $20 \%$ FR samples were evaluated a "moderately like" and "like very much" respectively. Therefore, the most acceptable biscuits at $25 \%$ fat replacement which had shown good hardness parameter and acceptable flavor. It was reported that cookies had given good general acceptance at $35 \%$ fat replacement with polydextrose [44]. 


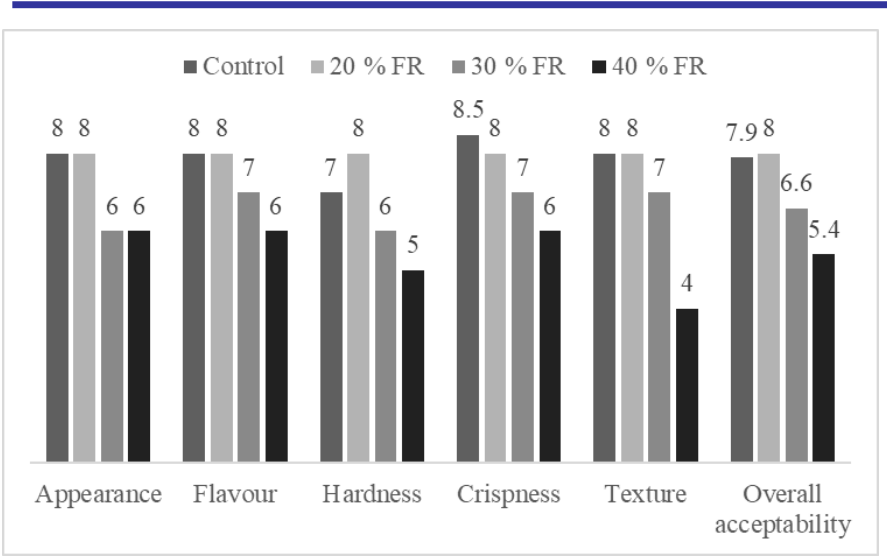

Sensory score of control and fat replaced (FR) biscuits

\section{CONCLUSION}

Microwave Assisted Extraction (MAE) of chia seed mucilage gave a better yield than the conventional extraction method. Its rheological properties correlated with the mucilage extracted through other techniques. Further optimization studies are yet to be done at different water seed ratio, time and power levels and seed particle size on mucilage yield and oil yield. The addition of chia mucilage as a fat replacer significantly affected the physico-chemical properties and sensory properties of biscuits. Energy value was reduced as a result of fat substitution. In sensory analysis, biscuits with $25 \%$ of fat replacement with chia mucilage gave overall acceptability similar to control biscuits. A comparative study on shelf life of various bakery products are yet to be done with mucilage extracted through various kind of extraction techniques. Therefore, a complete utilization of chia seed can be achieved thorough MAE for a better yield of oil and mucilage.

\section{ACKNOWLEDGEMENT}

The authors thank the JNTU, Ananthapur for supporting this study and M/s. SAMATH, Hyderabad for supplying the raw materials.

\section{REFERENCES}

[1] Porras-Loaiza, P., Jiménez-Munguía, M. T., Sosa-Morales, M. E. Palou, E., \& López-Malo, A. (2013). Physical properties, chemical characterization and fatty acid composition of Mexican chia (Salvia hispanicaL.) seeds. International Journal of Food Science \& Technology, 49(2), 571-577. doi:10.1111/ijfs.12339

[2] Coorey, R., Tjoe, A., \& Jayasena, V. (2014). Gelling Properties of Chia Seed and Flour. Journal of Food Science, 79(5), E859-E866. doi:10.1111/1750-3841.12444.

[3] Reyes-Caudillo, E., Tecante, A., \& Valdivia-López, M. A. (2008). Dietary fibre content and antioxidant activity of phenolic compounds present in Mexican chia (Salvia hispanica L.) seeds. Food Chemistry, 107(2), 656-663. doi:10.1016/j.foodchem.2007.08.062.

[4] Lin, K. Y., \& Daniel, J. R. (1994). Structure of chia seed polysaccharide exudates. Carbohydrate Polymer, 23, 13-18.

[5] Muñoz, L. A., Cobos, A., Diaz, O., \& Aguilera, J. M. (2012). Chia seeds: Microstructure, mucilage extraction and hydration. Journal of Food Engineering, 108(1), 216-224. doi:10.1016/j.jfoodeng.2011.06.037.

[6] Wang, L., \& Weller, C. L. (2006). Recent advances in extraction of nutraceuticals from plants. Trends in Food Science \& Technology, 17(6), 300-312. doi:10.1016/j.tifs.2005.12.004

[7] Felkai-Haddache, L., Dahmoune, F., Remini, H., Lefsih, K., Mouni, L., \& Madani, K. (2016). Microwave optimization of mucilage extraction from Opuntia ficus indica Cladodes. International Journal of Biological Macromolecules, $\quad 84, \quad 24-30$. doi:10.1016/j.ijbiomac.2015.11.090

[8] Felkai-Haddache, L., Remini, H., Dulong, V., Mamou-Belhabib, K. Picton, L., Madani, K., \& Rihouey, C. (2015). Conventional and Microwave-Assisted Extraction of Mucilage from Opuntia ficusindica Cladodes: Physico-Chemical and Rheological Properties. Food and Bioprocess Technology, 9(3), 481-492. doi:10.1007/s11947-015-1640-7

[9] Akoh, C.C. (1998). Fat replacers, Food Technology, 52, 47-52.

[10] https://www.who.int/news-room/fact-sheets/detail/obesity-andoverweight, 2018

[11] Misra, A., \& Khurana, L. (2010). Obesity-related noncommunicable diseases: South Asians vs White Caucasians. International Journal of Obesity, 35(2), 167-187. doi:10.1038/ijo.2010.135.

[12] Grundy SM, Brewer HB Jr, Cleeman JI, Smith SC Jr, Lenfant C. (2004). Definition of metabolic syndrome: Report of the National Heart, Lung, and Blood Institute/American Heart Association conference on scientific issues related to definition. Circulation, 109(3), 433-8.

[13] Zoulias, E. ., Oreopoulou, V., \& Tzia, C. (2002). Textural properties of low-fat cookies containing carbohydrate- or protein-based fat replacers. Journal of Food Engineering, 55(4), 337-342. doi:10.1016/s0260-8774(02)00111-5

[14] Alexander, R. J., \& Zobel, H. F. (1992). Developments in carbohydrate chemistry. St. Paul, AACC.

[15] Mitchell, H. L. (1996). The role of the bulking agent polydextrose in fat replacement. In S. Roller \& S. A. Jone (Eds.), Handbook of fat replacers, 235-249. Boca Raton:CRC Press.

[16] O’Brien, C. ., Mueller, A., Scannell, A. G. ., \& Arendt, E. . (2003) Evaluation of the effects of fat replacers on the quality of wheat bread. Journal of Food Engineering, 56(2-3), 265-267. doi:10.1016/s0260-8774(02)00266-2

[17] Krystyjan, M., Gumul, D., Ziobro, R., \& Sikora, M. (2015). The Effect of Inulin as a Fat Replacement on Dough and Biscui Properties. Journal of Food Quality, 38(5), 305-315. doi:10.1111/jfq.12148.

[18] Lee, Y., \& Puligundla, P. (2016). Characteristics of reduced-fat muffins and cookies with native and modified rice starches. Emirates Journal of Food and Agriculture, 28(5), 311. doi:10.9755/ejfa.2015 05-227.

[19] Sudha, M. L., Srivastava, A. K., Vetrimani, R., \& Leelavathi, K (2007). Fat replacement in soft dough biscuits: Its implications on dough rheology and biscuit quality. Journal of Food Engineering, 80(3), 922-930. doi:10.1016/j.jfoodeng.2006.08.006.

[20] http://www.fnbnews.com/Bakery-Biscuits/indian-biscuit-marketprojected-to-reach-725 billionin-next-four-years-42107

[21] Felisberto, M. H. F., Wahanik, A. L., Gomes-Ruffi, C. R., Clerici, M. T. P. S., Chang, Y. K., \& Steel, C. J. (2015). Use of chia (Salvia hispanica L.) mucilage gel to reduce fat in pound cakes. LWT - Food Science and Technology, 63(2), 1049-1055. doi:10.1016/j.lwt.2015.03.114

[22] Fernandes, Sibele \& Salas-Mellado, Myriam. (2017). Addition of chia seed mucilage for reduction of fat content in bread and cakes. Food Chemistry. 227. 10.1016/j.foodchem.2017.01.075

[23] Campos, B. E., Dias Ruivo, T., da Silva Scapim, M. R., Madrona, G. S., \& de C. Bergamasco, R. (2016). Optimization of the mucilage extraction process from chia seeds and application in ice cream as a stabilizer and emulsifier. LWT - Food Science and Technology, 65, 874-883. doi:10.1016/j.lwt.2015.09.021

[24] Ranganna S. (1986). Handbook of Analysis and Quality Control for Fruit and Vegetable Products. Tata McGraw-Hill Publishing Company, New Delhi, India. 124-125.

[25] Purlis, E., Salvadori, V. O. (2007): Bread browning kinetics during baking, Journal of Food Engineering, 80 (4), 1107-1115.

[26] AOAC - Association of Official Analytical Chemists (2005). Official Methods of Analyses of the Association of Analytical Chemists (18th ed.).

[27] Ayerza, R., Coates, W. (2001). Chia Seeds: New Source of Omega-3 Fatty Acids, Natural Antioxidants and Dietetic Fiber. Southwes Center for Natural Products Research and Commercialization, Office of Arid Lands Studies, Tucson, Arizona, USA

[28] Marin, F.M., Acevedo, M.J., Tamez, R.M., Nevero, M.J., Garay, A.L., 2008. WO/2008/0044908 Method for Obtaining Mucilage from Salvia hispanica L. Word International Property Organization. 
[29] Shah N, A. K. Seth and B. S. Nayak. (2018). Microwave assisted isolation of mucilage from the Trichosanthes Dioca Fruit. IJPSR.0975-8232.1(5).68-72.

[30] Rajvi V. Desai , Biren N. Shah , Alisha P. Patel. (2014). Microwave Assisted Isolation of Mucilage from the Trigonella foenum graecum Seeds. International. Journal of. Pharmaceutical. Science Reviews, 25(2), 15, 80-82.

[31] Brookfield, (2009). More solutions to sticky problems- a guide to getting more from your Brookfield viscometer, MA, USA: Brookfield Engineering labs Inc.

[32] Sharma SK, Mulvaney SJ, Rizvi SSH (1999) Food processing engineering: theory and laboratory experiments. Wiley, Hoboken.

[33] Samavati, V., \& Skandari, F. (2014). Recovery, chemical and rheological characterization of gum from Assyrian pulm International Journal of Biological Macromolecules, 67, 172-179. doi:10.1016/j.ijbiomac.2014.03.017.

[34] Tavares, L. S., Junqueira, L. A., de Oliveira Guimarães, I. C., \& de Resende, J. V. (2017). Cold extraction method of chia seed mucilage (Salvia hispanica L.): effect on yield and rheological behavior Journal of Food Science and Technology, 55(2), 457-466. doi:10.1007/s13197-017-2954-4

[35] Capitani, M. I., Corzo-Rios, L. J., Chel-Guerrero, L. A., BetancurAncona, D. A., Nolasco, S. M., \& Tomás, M. C. (2015). Rheological properties of aqueous dispersions of chia (Salvia hispanica L.) mucilage. Journal of Food Engineering, 149, 70-77. doi:10.1016/j.jfoodeng.2014.09.043

[36] Timilsena, Y. P., Adhikari, R., Kasapis, S., \& Adhikari, B. (2015) Rheological and microstructural properties of the chia seed polysaccharide. International Journal of Biological Macromolecules, 81,991-999. doi:10.1016/j.ijbiomac.2015.09.040

[37] Segura-Campos, M., Acosta-Chi, Z., Rosado-Rubio, G., ChelGuerrero, L., \& Betancur-Ancona, D. (2014). Whole and crushed nutlets of chia (Salvia hispanica) from Mexico as a source of functional gums. Food Science and Technology (Campinas), 34(4), 701-709. doi:10.1590/1678-457x.6439
[38] Dadkhah, A., Hashemiravan, M., \& Seyedain-Ardebili, M. (2012) Effect of shortening replacement with nutrim oat bran on chemical and physical properties of shortened cakes. Annals of Biological Research, 3, 2682-2687.

[39] Fernandes, Sibele \& Salas-Mellado, Myriam. (2017). Addition of chia seed mucilage for reduction of fat content in bread and cakes. Food Chemistry. 227. 10.1016/j.foodchem.2017.01.075.

[40] Budžaki, S., Koceva Komlenić, D., Lukinac Cačić, J., Cačić, F., .. Jukić, M. (2014). Influence of cookies composition on temperature profiles and qualitative parameters during baking. Croatian Journal of Food Science and Technology, 6(2), 72-78. doi:10.17508/cjfst.2014.6.2.02

[41] Chauhan, A., Saxena, D. C., \& Singh, S. (2016). Physical, textural, and sensory characteristics of wheat and amaranth flour blend cookies. Cogent Food \& Agriculture, 2(1). doi:10.1080/23311932.2015.1125773

[42] Bala, A., Gul, K., \& Riar, C. S. (2015). Functional and sensory properties of cookies prepared from wheat flour supplemented with cassava and water chestnut flours. Cogent Food \& Agriculture, 1(1) doi:10.1080/23311932.2015.1019815

[43] Oluwamukomi, M. O., Oluwalana, I. B., \& Akinbowale, O. F. (2011). Physicochemical and sensory properties of wheat-cassava Composite biscuit enriched with soy flour. African Journal of Food Science, 5(2), 50-56

[44] Zoulias, E. I., Oreopoulou, V., \& Tzia, C. (2000). Effect of fat mimetics on physical, textural and sensory properties of cookies. International Journal of Food Properties, 3(3), 385-397. doi:10.1080/10942910009524643

[45] Campbell L. A., Ketelsen S. M., and Antenucci R. N. (1994) Formulating oatmeal cookies with calorie-sparing ingredients. Food Technology. 48(5): 98-105.

[46] Borneo, R., Aguirre, A., \& León, A. E. (2010). Chia (Salvia hispanica L) Gel Can Be Used as Egg or Oil Replacer in Cake Formulations. Journal of the American Dietetic Association, 110(6), 946-949. doi:10.1016/j.jada.2010.03.011 